Revista Brasileira de Farmacognosia Brazilian Journal of Pharmacognosy 21(2): 334-339, Mar./Apr. 2011

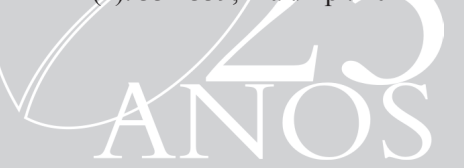

Article

Received 2 Jan 2011

Accepted 23 Jan 2011

Available online 13 May 2011

Keywords:

conservation

in vitro culture

micropropagation

plant growth regulators

Rhodophyta

ISSN 0102-695X

doi: $10.1590 /$ S0102-695X2011005000077

\section{Micropropagation as a tool for sustainable utilization and conservation of populations of Rhodophyta}

\author{
Nair S. Yokoya, ${ }^{* 1}$ Yocie Yoneshigue-Valentin ${ }^{2}$ \\ ${ }^{1}$ Instituto de Botânica, Núcleo de Pesquisas em Ficologia, Brazil, \\ ${ }^{2}$ Departamento de Botânica, Instituto de Biologia, Universidade Federal do \\ Rio de Janeiro, Brazil.
}

\begin{abstract}
Micropropagation as a tool for sustainable utilization and conservation of populations of Rhodophyta. Micropropagation, or in vitro clonal propagation, allows the production of a large number of individuals within a short period. These micropropagated clones could be used as seedlings for seaweed cultivation, avoiding collection from natural beds. Consequently, there has been an increasing interest in micropropagation as a tool for preservation of populations of marine red algae on the Brazilian coast and for the sustainable production of raw material for commercial exploration. This paper reviews the literature on tissue culture and micropropagation of red algae published during the three last decades. Based on the literature, we can conclude that the regeneration process is complex and diversified in different species of Rhodophyta and that the success of micropropagation depends on this process. Species belonging to the orders Bangiales and Ceramiales showed low potential for regeneration, while Gigartinales species showed the highest potential for regeneration. Micropropagation of commercially important red algae is fundamental for the conservation of natural populations by providing seedlings for cultivation and for germplasm collections, both for the conservation of genetic diversity and for biotechnological applications.
\end{abstract}

\section{Introduction}

Seaweed tissue culture is an important tool for micropropagation, as well as for the selection of high-yield strains or those with interesting commercial characteristics. Micropropagation, or in vitro clonal propagation, permits the production of a large number of individuals within a short period. These can then be used as seedlings for seaweed cultivation, rather than collecting them from natural beds. This had generated an increasing interest in micropropagation as a tool for the preservation of populations of marine red algae and for the sustainable production of raw materials of commercial interest (Scheme 1).

Micropropagation is based on cell totipotency, which is the capacity of a single vegetative cell to divide and differentiate to generate a new organism. This phenomenon is the basis of plant tissue culture and is used to analyze the physiological and biochemical processes of plant differentiation and development.

Tissue culture (or in vitro culture) is defined as the axenic culture of any part of one organism (called an explant) under controlled conditions in a culture medium. Seaweed tissue culture differs from unialgal culture in relation to the axenic condition (without bacteria and fungi) and some of the characteristics of the culture medium used for the tissue culture (Yokoya, 1996). Although the thallus of seaweed does not differentiate into tissue, the term "tissue culture" is used to refer to the axenic conditions of seaweed culture using different explants (thallus segments, cortical and/or medullar regions, filaments, and callus).

The first attempt to cultivate seaweed explants under axenic conditions was performed by Aharon Gibor in 1950 (Polne-Fuller, 1988). However, the procedures used for plant tissue culture were not suitable for seaweeds due to two main factors: the difficulties in obtaining axenic algal explants and the poor knowledge of the physiological processes involved in seaweed development, including the role played by plant growth regulators (Polne-Fuller, 1988). In 1978, Chen \& Taylor described the axenic culture of the medullar region of Chondrus crispus Stackhouse (Rhodophyta), which could be considered the first successful seaweed tissue culture. Following their publication, several studies were carried out in order to develop methods for obtaining axenic explants and to investigate the factors that affect seaweed tissue culture. For successful seaweed tissue 
culture, it is of fundamental importance to know the physiology of seaweed and the factors that control seaweed development. These factors can be divided into two groups: endogenous factors (related to explant characteristics such as origin, physiological state, stage of life history, age etc) and exogenous factors (such as temperature, salinity, irradiance, photoperiod, chemical composition and $\mathrm{pH}$ of the culture medium, state of medium (liquid or solid), addition of plant growth regulators and/or inorganic carbon to the culture medium).

\section{Plant growth regulators (PGR) in Rhodophyta}

The main objective of the first publications on seaweed tissue culture was to investigate callus induction and growth in different species of red algae (Table 1). Polne-Fuller \& Gibor (1987) described callus formation in nine species of rhodophytes, including species belonging to the genera Porphyra, Gelidium, Gracilaria, Eucheuma, Gigartina and Prionitis, but regeneration from callus was not observed. Similar results were reported by Gusev et al. (1987) for species of Ceramium, Laurencia, Gracilaria, Furcellaria and Phyllophora and also by Liu \& Gordon (1987) for Pterocladiella capillacea. Other studies reported similar results for Porphyra umbilicalis (Liu \&
Kloareg, 1991), Grateloupia doryphora (Robaina et al., 1990), Eucheuma denticulatum (Dawes \& Koch, 1991), Laurencia sp. (Robaina et al., 1992), Gracilaria verrucosa (Kaczyna \& Megnet, 1993) and Solieria filiformis (Robledo \& Garcia-Reina, 1993).

Regeneration from callus was reported for Agardhiella subulata (Bradley \& Cheney, 1990) and Grateloupia filiformis (Yokoya et al., 1993), which belong to the order Gigartinales. Huang \& Fujita (1996) studied ten species of Gigartinales and, among these, six species showed potential for regeneration from callus, notably the genera Carpopeltis, Grateloupia and Prionitis. Species of Grateloupia showed the highest regeneration potential, which could be increased by the addition of plant growth regulators (auxins and/ or cytokinins), as reported for Grateloupia dichotoma by Yokoya \& Handro (1996, 1997). For other species of Gigartinales, regeneration from callus was found to be stimulated by PGR in Solieria filiformis (Yokoya \& Handro, 2002), Hypnea musciformis (Yokoya et al., 2003) and Kappaphycus alvarezii (Muñoz et al., 2006). However, the presence of PGR was facultative for the last two species, as reported by Bravin et al. (2006) and Reddy et al. (2003), respectively.

In contrast to Gigartinales species, in species belonging to Gracilariales the PGR play an important role in inducing the regeneration process, stimulating

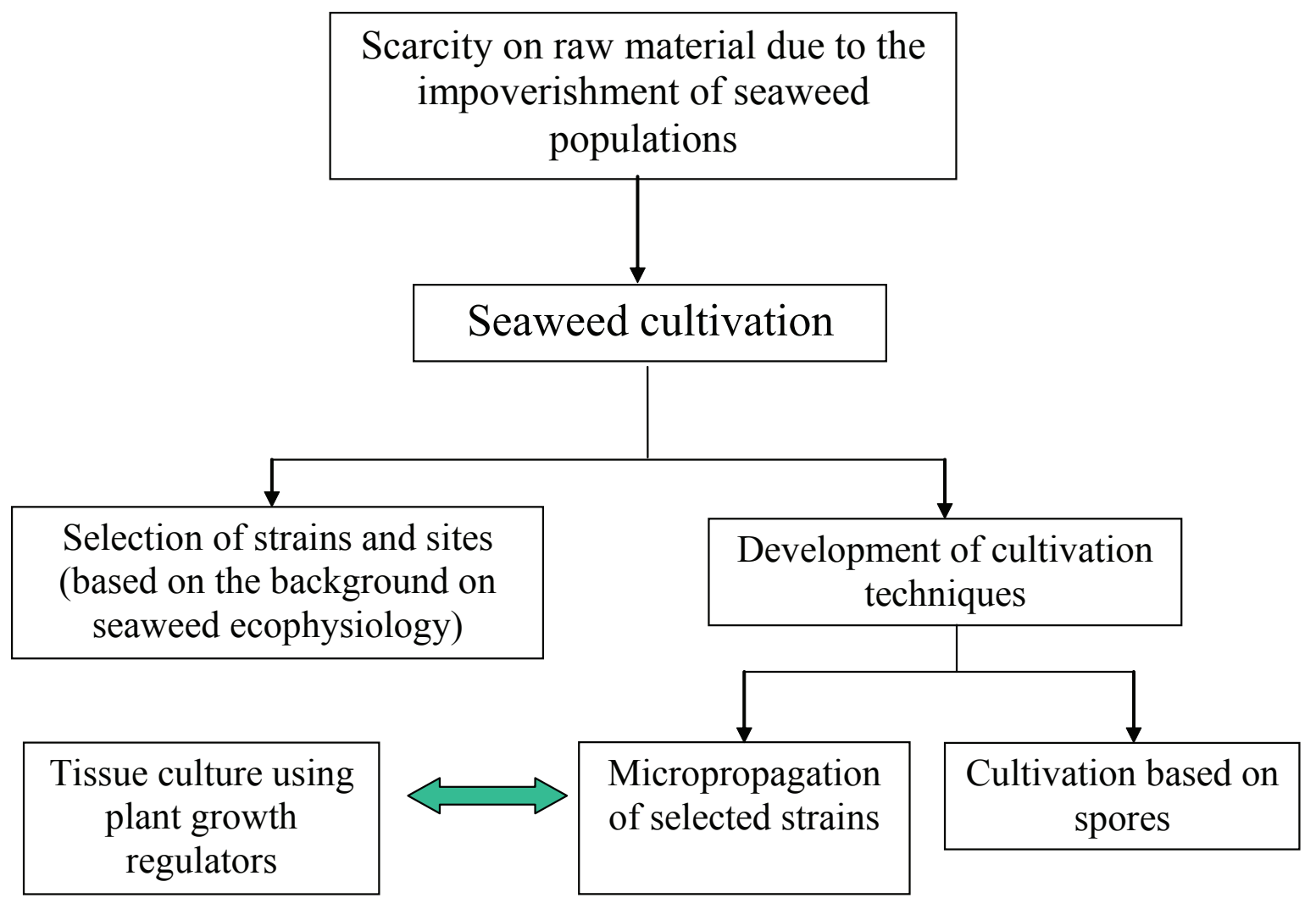

Scheme 1. Flow diagram of the steps involved in the utilization of micropropagation as a tool for the conservation of seaweed populations and for sustainable production of raw material of commercial interest. 
cell differentiation in the callus of Gracilaria vermiculophylla (Yokoya et al., 1999), G. chilensis (Collantes et al., 2004), G. domingensis (Ramlov, 2007), G. perplexa and G. tenuistipitata (Yokoya et al., 2004), and Gracilariopsis tenuifrons (Yokoya, 2000).

Based on studies published during the last three decades, we can conclude that the regeneration from callus is complex and diversified in the different species of Rhodophyta and that the success on micropropagation will ultimately depend on this process. The data indicate the need for further investigation into the role played by PGR on cell processes (division, elongation, and differentiation) in the different species, considering the potential for regeneration of each order. Species belonging to the orders Bangiales and Ceramiales showed low potential for regeneration from callus, while Gigartinales species showed the highest potential (Table 1).

\section{Biotechnological applications}

Few studies have reported the use of micropropagation for biotechnological applications and improvement in this field needs to be achieved. Maliakal et al. (2001) reported the production of halogenated compounds from adventitious plantlets regenerated from callus of Ochtodes secundiramea, and Reddy et al. (2003) selected specimens originated from micropropagules regenerated from callus of Kappaphycus alvarezii that had higher growth rates than specimens farmed in India.

Table 1. Effects of plant growth regulators (PGR, auxins and cytokinins) on callus formation and thallus regeneration from callus in some species of Rhodophyta. Modified from Yokoya (2007).

\begin{tabular}{|c|c|c|c|c|}
\hline \multirow{2}{*}{ Species } & \multirow{2}{*}{$\begin{array}{c}\text { Callus } \\
\text { PGR }\end{array}$} & \multicolumn{2}{|c|}{ Regeneration from callus } & \multirow{2}{*}{ References } \\
\hline & & & PGR & \\
\hline \multicolumn{5}{|l|}{ BANGIALES } \\
\hline Porphyra lanceolata (Setchell \& Hus) G.M. Smith & $\mathrm{N}$ & - & NT & Polne-Fuller \& Gibor (1987) \\
\hline Porphyra nereocystis C.L. Anderson & $\mathrm{N}$ & - & NT & Polne-Fuller \& Gibor (1987) \\
\hline Porphyra perforata J. Agardh & $\mathrm{N}$ & - & NT & Polne-Fuller \& Gibor (1987) \\
\hline Porphyra umbilicalis (L.) Kuetzing & ST & - & NT & Liu \& Kloareg (1991) \\
\hline Smithora naiadum (C.L. Anderson) G.J. Hollenberg & $\mathrm{N}$ & - & NT & Polne-Fuller \& Gibor (1987) \\
\hline \multicolumn{5}{|l|}{ CERAMIALES } \\
\hline Ceramium kondoi Yendo & $\mathrm{ST}$ & - & NT & Gusev et al. (1987) \\
\hline Laurencia paniculata Kuetzing & ST & - & NT & Gusev et al. (1987) \\
\hline Laurencia sp. & NT & - & NT & Robaina et al. (1992) \\
\hline Laurencia undulata Yamada & ES & - & NT & Huang \& Fujita (1996) \\
\hline \multicolumn{5}{|l|}{ GELIDIALES } \\
\hline Gelidiella acerosa (Forsskål) Feldmann \& G. Hamel & $\mathrm{N}$ & + & $\mathrm{N}$ & Kumar et al. (2004) \\
\hline Gelidium nudifrons N.L. Gardner & $\mathrm{N}$ & - & NT & Polne-Fuller \& Gibor (1987) \\
\hline $\begin{array}{l}\text { Gelidium robustum (N.L. Gardner) Hollenberg \& } \\
\text { I.A. Abbott }\end{array}$ & $\mathrm{N}$ & - & NT & Polne-Fuller \& Gibor (1987) \\
\hline Gelidium vagum Okamura & ST & - & NT & Gusev et al. (1987) \\
\hline Gelidium versicolor (Gmel.) Lamour. & NT & + & NT & Garcia-Reina et al. (1988) \\
\hline $\begin{array}{l}\text { Pterocladiella capillacea (S.G. Gmelin) Santelices \& } \\
\text { Hommersand (as Pterocladia capillacea) }\end{array}$ & ES & - & NT & Liu \& Gordon (1987) \\
\hline Ptilophora subcostata (Okamura) N.E. Norris & ST & - & NT & Huang \& Fujita (1996) \\
\hline \multicolumn{5}{|l|}{ GRACILARIALES } \\
\hline Gracilaria chilensis Bird, McLachlan \& Oliveira & NT & + & NT & Collantes et al. (2004) \\
\hline Gracilaria domingensis (Kutzing) Sonder ex Dickie & ST & + & $\mathrm{ST}$ & Ramlov (2007), Ramlov et al. (2009) \\
\hline Gracilaria papenfussi I.A. Abbott & $\mathrm{N}$ & - & NT & Polne-Fuller \& Gibor (1987) \\
\hline Gracilaria perplexa Byrne \& Zuccarello & ST & + & $\mathrm{ST}$ & Yokoya et al. (2004) \\
\hline Gracilaria tenuistipitata Chang \& Xia & ST & + & ST & Yokoya et al. (2004) \\
\hline Gracilaria textorii Hariot & $\mathrm{N}$ & - & NT & Huang \& Fujita (1996) \\
\hline Gracilaria verrucosa (Hudson) Papenfuss & ST & - & NT & $\begin{array}{c}\text { Gusev et al. (1987); Kaczyna \& } \\
\text { Megnet (1993) }\end{array}$ \\
\hline
\end{tabular}




\begin{tabular}{|c|c|c|c|c|}
\hline Gracilaria vermiculophylla (Ohmi) Papenfuss & ST & + & ST & Yokoya et al. (1999) \\
\hline $\begin{array}{l}\text { Gracilariopsis tenuifrons (Bird \& Oliveira) Fredericq } \\
\text { \& Hommersand }\end{array}$ & ES & + & ST & Yokoya (2000) \\
\hline \multicolumn{5}{|l|}{ RHODYMENIALES } \\
\hline Rhodymenia pertusa (Postels \& Ruprecht) J. Agardh & ST & - & NT & Gusev et al. 1987 \\
\hline \multicolumn{5}{|l|}{ GIGARTINALES } \\
\hline Agardhiella subulata (C. Agardh) Kraft & ES & + & ST & Bradley \& Cheney (1990) \\
\hline Ahnfeltiopsis flabelliformis (Harvey) Masuda & ST & - & NT & Huang \& Fujita (1996) \\
\hline Carpopeltis affinis (Harvey) Okamura & ST & + & NT & Huang \& Fujita (1996) \\
\hline Carpopeltis prolifera Kawaguchi et Masuda & ST & + & NT & Huang \& Fujita (1996) \\
\hline Chondracanthus tenellus (Harvey) Hommersand & ST & - & NT & Huang \& Fujita (1996) \\
\hline $\begin{array}{l}\text { Eucheuma denticulatum (N.L. Burman) F.S. Collins } \\
\text { \& Hervey }\end{array}$ & ES & - & NT & Dawes \& Koch (1991) \\
\hline Eucheuma uncinatum Setchell \& Gardner & $\mathrm{N}$ & - & NT & Polne-Fuller \& Gibor (1987) \\
\hline Furcellaria fastigiata (Turner) J.V. Lamour. & ST & - & NT & Gusev et al. (1987) \\
\hline Gigartina exasperate Harvey \& Barley & $\mathrm{N}$ & - & NT & Polne-Fuller \& Gibor (1987) \\
\hline Gloiopeltis tenax (Turner) Decaisne & $\mathrm{ST}$ & - & NT & Huang \& Fujita (1996) \\
\hline Grateloupia acuminata Holmes & ST & + & NT & Huang \& Fujita (1996) \\
\hline Grateloupia dichotoma J. Agardh & ST & + & ST & Yokoya \& Handro (1996; 1997) \\
\hline Grateloupia doryphora (Montagne) M.A. Howe & NT & - & NT & Robaina et al. (1990) \\
\hline Grateloupia filicina C. Agardh & $\mathrm{ST}$ & + & NT & Huang \& Fujita (1996) \\
\hline Grateloupia filiformis Kuetzing & NT & + & NT & Yokoya et al. (1993) \\
\hline Grateloupia imbricata Holmes & $\mathrm{ST}$ & + & NT & Huang \& Fujita (1996) \\
\hline Grateloupia turuturu Yamada & $\mathrm{ST}$ & + & NT & Huang \& Fujita (1996) \\
\hline Hypnea musciformis (Wulfen in Jacqu.) J.V. & ST & + & ST & Yokoya et al. (2003); \\
\hline Lamour. & NT & - & NT & Bravin et al. (2006) \\
\hline Kappaphycus alvarezii (Doty) Doty ex P.C. Silva & $\mathrm{N}$ & + & $\mathrm{N}$ & Reddy et al. (2003); \\
\hline Kappaphycus alvarezii & $\mathrm{ST}$ & + & ST & $\begin{array}{l}\text { Muñoz et al. (2006); Hayashi et al. } \\
\text { (2008) }\end{array}$ \\
\hline Meristotheca papulosa J. Agardh & ST & + & NT & Huang \& Fujita (1997) \\
\hline Ochtodes secundiramea (Montagne) M.A. Howe & NT & + & NT & Maliakal et al. (2001) \\
\hline Phyllophora nervosa (A.P. de Candolle) Greville & ST & - & NT & Gusev et al. (1987) \\
\hline Prionitis crispata Kawaguchi & ST & + & NT & Huang \& Fujita (1996) \\
\hline Prionitis lanceolata (Harvey) Harvey & $\mathrm{N}$ & - & NT & Polne-Fuller \& Gibor (1987) \\
\hline Solieria filiformis (Kuetzing) Gabrielson & NT & - & NT & Robledo \& Garcia-Reina (1993) \\
\hline Solieria filiformis & $\mathrm{N}$ & + & ST & Yokoya \& Handro (2002) \\
\hline
\end{tabular}

ST: stimulatory effect; ES: plant hormones (auxins and cytokinins) are essential and their effects are stimulatory; N: without effect; NT: not tested; -: absence of thallus regeneration; +: presence of thallus regeneration.

\section{Conclusions}

Production and selection of new seaweed strains could improve the synthesis of natural products with different biological activities, as well as the commercial cultivation of seaweeds via the utilization of higher yield strains. Moreover, micropropagation of the commercially important red algae is fundamental for the conservation of natural populations, providing seedlings for cultivation and for germplasm collections. These seedlings could be used both for the preservation of genetic diversity and in biotechnological applications.

\section{Acknowledgments}

The authors thank the Conselho Nacional de Desenvolvimento Científico e Tecnológico, Brazil, financial support via grants $n^{\circ} 309672 / 2007-4$ to NSY and $n^{\circ} 309929 / 2009-1$ to YYV. This research was also supported by a Grant from the Fundação de Auxílio à Pesquisa do Estado de São Paulo, Brazil, to the first author. 


\section{References}

Bradley PM, Cheney DP 1990. Some effects of plant regulators on tissue cultures of the marine red alga Agardhiella subulata (Gigartinales, Rhodophyta). Hydrobiologia 204/205: 353-360.

Bravin IC, Yoneshigue-Valentin Y, Yokoya NS 2006. Formação de calos e regeneração de segmentos apicais de Hypnea musciformis (Wulfen) Lamouroux (Gigartinales, Rhodophyta): obtenção de culturas axênicas e efeitos de diferentes concentrações de ágar. Rev Bras Bot 29: 175-182.

Chen LC-M, Taylor ARA 1978. Medullary tissue culture of the red alga Chondrus crispus. Can J Bot 56: 883-886.

Collantes G, Melo C, Candia A 2004. Micropropagation by explants of Gracilaria chilensis Bird, McLachlan and Oliveira. J Appl Phycol 16: 203-213.

Dawes CJ, Koch EW 1991 Branch, micropropagule and tissue culture of the red algae Eucheuma denticulatum e Kappaphycus alvarezii farmed in Philippines. J Appl Phycol 3: 247-257.

Garcia-Reina G, Robaina R, Luque A 1988. Attempts to establish axenic cultures and photoautotrophic growth of Gelidium versicolor, Gracilaria ferox and Laurencia sp. In Stadler T, Mollion J, Verdus M-C, Karamanos Y, Christiaen MH (eds) Algal Biotechnology. Elsevier, p. 111-118

Gusev MV, Tambiev AH, Kikova NN, Shelyastina NN, Aslanyan RR 1987. Callus formation in seven species of agarophyte marine algae. Mar Biol 95: 593-597.

Hayashi L, Yokoya NS, Kikuchi DM, Oliveira EC 2008. Callus induction and micropropagation improved by colchicine and phytoregulators in Kappaphycus alvarezii (Rhodophyta, Solieriaceae). J Appl Phycol 20: 653-659.

Huang W, Fujita Y 1996. Callus induction and thallus regeneration in some species of red algae. Phycol Res 45: 105-111.

Huang W, Fujita Y 1997. Callus induction and thallus regeneration of the red alga Meristotheca papulosa (Rhodophyta, Gigartinales). Bot Mar 40: 55-61.

Kaczyna F, Megnet R 1993. The effects of glycerol and plant growth regulators on Gracilaria verrucosa (Gigartinales, Rhodophyceae). Hydrobiologia 268: 57-64.

Kumar GR, Reddy CRK, Ganesan M, Thiruppathi S, Dipakkore S, Eswaran K, Subba Rao PV, Jha B 2004. Tissue culture and regeneration of thallus from callus of Gelidiella acerosa (Gelidiales, Rhodophyta). Phycologia 43: 596602.

Liu XW, Gordon ME 1987. Tissue and cell culture of New Zealand Pterocladia and Porphyra species. Hydrobiologia 151/152: 147-154.

Liu XW, Kloareg B 1991. Tissue culture of Porphyra umbilicalis (Bangiales, Rhodophyta). I. The effects of plant hormones on callus induction from tissue explants. $C R$ Academic Paris Serie III 321: 517-522.

Maliakal S, Cheney C, Rorrer G 2001. Halogenated monoterpene production in regenerated plantlet cultures of Ochtodes secundiramea (Rhodophyta, Cryptonemiales). J Phycol 37: 1010-1019.

Muñoz J, Cahue-López AC, Patiño R, Robledo D 2006. Use of plant growth regulators in micropropagation of Kappaphycus alvarezii (Doty) in airlift bioreactors. $J$ Appl Phycol 18: 209-218.

Polne-Fuller M 1988. The past, present, and future, of tissue culture and biotechnology of seaweeds. In Stadler T, Mollion J, Verdus M-C, Karamanos Y \& Christiaen MH (eds) Algal Biotechnology. Elsevier p. 17-31.

Polne-Fuller M, Gibor A 1987. Calluses and callus-like growth in seaweeds: induction and culture. Hydrobiologia 151/152: 131-138.

Ramlov F 2007. Efeitos dos fitorreguladores e da irradiância no crescimento e na morfogênese de morfos pigmentares de Gracilaria domingensis (Kutzing) Sonder ex Dickie (Gracilariales, Rhodophyta). São Paulo, 101 p. Dissertação de Mestrado, Programa de Pós-graduação em Biodiversidade Vegetal e Meio Ambiente, Instituto de Botânica.

Ramlov F, Plastino EM, Yokoya NS 2009. Efeitos do ágar no crescimento de explantes e na formação de calos em morfos pigmentares de Gracilaria domingensis (Kutzing) Sonder ex Dickie (Gracilariales, Rhodophyta). Rev Bras Bot 32: 605-614.

Reddy CRK, Kumar GRK, Siddhanta AK, Tewari A 2003. In vitro somatic embryogenesis and regeneration of somatic embryos from pigmented callus of Kappaphycus alvarezii (Doty) Doty (Rhodophyta, Gigartinales). J Phycol 39: 610-616.

Robaina RR, Garcia P, García-Jimenez P, Luque A 1990. Morphogenetic effect of glycerol on tissue cultures of the red seaweed Grateloupia doryphora. J Phycol 2: 137-143.

Robaina RR, García-Jimenez P, Luque A 1992. The growth pattern and structure of callus from the red alga Laurencia sp. (Rhodophyta, Ceramiales) compared to shoot regeneration. Bot Mar 35: 267-272.

Robledo DR, Garcia-Reina G 1993. Apical callus formation in Solieria filiformis (Gigartinales, Rhodophyta) cultured in tanks. Hydrobiologia 260/261: 401-406.

Yokoya NS 1996. Controle do crescimento e da morfogênese por auxinas e citocininas em três espécies de rodofíceas: Gracilariopsis tenuifrons, Grateloupia dichotoma e Solieria filiformis. São Paulo, 209 p. Tese de Doutorado, Instituto de Biociências, Universidade de São Paulo.

Yokoya NS 2000. Apical callus formation and plant regeneration controlled by plant growth regulators on axenic culture of the red alga Gracilariopsis tenuifrons (Gracilariales, Rhodophyta). Phycol Res 48: 133-142.

Yokoya NS 2007. Compostos biologicamente ativos de algas 
marinhas e perspectivas de aplicação em novos fármacos: A importância da propagação in vitro de macroalgas marinhas como subsídio para a produção sustentável de seus derivados, com ênfase nas Rhodophyta. In Barbosa LM \& Santos NA (org.). A Botânica no Brasil. pesquisa, ensino e políticas públicas ambientais. São Paulo: Secretaria do Meio Ambiente, p. 155-158.

Yokoya NS, Handro W 1996. Effects of auxins and citokinin on tissue culture of Grateloupia dichotoma (Gigartinales, Rhodophyta). Hydrobiologia 326/327: 393-400.

Yokoya NS, Handro W 1997. Thallus regeneration and growth induced by plant growth regulators and light intensity in Grateloupia dichotoma (Rhodophyta). In Kitamura $\mathrm{T}$ (ed.) Proceedings of I.T.I.T. International Symposium on New Technologies from Marine-Sphere. Takamatsu: Shikoku National Industrial Research Institute, p. 8386.

Yokoya NS, Handro W 2002. Effects of plant growth regulators and culture medium on morphogenesis of Solieria filiformis (Rhodophyta) cultured in vitro. J Appl Phycol 14: 97-102.

Yokoya NS, Guimarães SMPB, Handro W 1993. Development of callus-like structures and plant regeneration in thallus segments of Grateloupia filiformis Kützing
(Rhodophyta). Hydrobiologia 260/261: 407-413.

Yokoya NS, Kakita H, Obika H, Kitamura T 1999. Effects of environmental factors and plant growth regulators on growth of the red alga Gracilaria vermiculophylla from Shikoku Island, Japan. Hydrobiologia 398: 339-347.

Yokoya NS, Plastino EM, Artel R 2003. Physiological responses and pigment characterization of two colour strains of the carrageenophyte Hypnea musciformis (Rhodophyta). In Chapman ARO, Anderson RJ, Vreeland VJ, Dawison JR (eds.) Proceedings of the XVII International Seaweed Symposium. New York: Oxford University Press, p. 425-433.

Yokoya NS, West JA, Luchi AE 2004. Effects of plants growth regulators on callus formation, growth and regeneration in axenic tissue cultures of Gracilaria tenuispitata and Gracilaria perplexa (Gracilariales, Rhodophyta). Phycol Res 52: 244-254.

\section{*Correspondence}

Nair S. Yokoya

Núcleo de Pesquisa em Ficologia, Instituto de Botânica Caixa Postal 3005, 01031-970 São Paulo-SP, Brazil nyokoya@pq.cnpq.br

Tel.: +55115067 6121 